\title{
The Study of Virtual Fitting Room in China
}

\author{
Mingyu Lu ${ }^{1, *}$, Suyin Chen ${ }^{2,+}$, Haotian $\mathrm{Lin}^{3,+}$, Yueyi $\mathrm{Li}^{4,+}$ \\ ${ }^{1}$ School of Science, Xi'an Jiaotong-Liverpool University, Suzhou, 215000, China, 1976169935@qq.com \\ ${ }^{2}$ Moses Brown School, Providence, Rhode Island, 029106, United States, monicachen23@mosesbrown.org \\ ${ }^{3}$ Miami University in Oxford, Ohio, 45056, United States, lin_yl1202@yahoo.com \\ ${ }^{4}$ Guangzhou Foreign Language School, Guangzhou, 511455, China, yurili1019475142@Gmail.com \\ + They are all second authors.
}

\begin{abstract}
With the increasing maturity of virtual fitting technology, this paper analyzes its marketing environment from three aspects: online apparel consumers, e-commerce trends and relevant national preferential policies, and combines the internal and external factors of the country to elaborate the current situation and trends of virtual fitting room development in China. Through a questionnaire survey, the challenges and new opportunities encountered by online virtual technology are jointly discussed, thus facilitating the widespread promotion and application of virtual fitting rooms.
\end{abstract}

Keywords : virtual fitting room, E-commerce, technology, survey results

\section{INTRODUCTION}

In recent years, with the rapid development of the technology, virtual reality has gradually become the trend of the times. With the rapid development of technology, the virtual fitting room technology has come into being, which is applied in both physical and online stores. For the online part, compared with the traditional offline shopping method, online shopping is not bound by time and space. However, for the clothing retail industry, different brands have different materials and sizes, and it is difficult for users to have accurate assessment and control of clothing sizes. Users can simply scan their body contours and input relevant body data to browse and try on their favorite clothes online. Online virtual fitting rooms provide a platform for users to quickly try on clothes, allowing consumers to get the right size of products in a short period of time. For the instore part, Offline users are able to experience convenient and fast virtual changing technology in physical stores, saving dressing time and improving shopping efficiency. At the same time, stores are able to reduce the cost of fitting rooms and gain more display and shopping space.Virtual fitting technology can not only significantly improve the efficiency of consumer purchases and greatly reduce the return rate, but also help companies grasp more user data, analyze this data to accurately recommend products for users, design new products based on demand, and reorganize promotion and marketing models, thus enabling brands to increase profits[1]. The virtual fitting room has attracted worldwide attention as a highly promising and mature online virtual fitting technology.

\section{OVERVIEW OF THE CURRENT SITUATION OF VIRTUAL FITTING ROOM}

\subsection{Definition}

According to Yang and Xiong, virtual fitting room enables users to personalize a $3 \mathrm{~d}$ model and fit clothes on with that model [2]. When it comes to the advanced virtual room, it even allows users to see the texture well as the models(images) are zoomable with a 360-degree view.

In fact, this technology has been applied the beauty industry. For example, with this technology, Sephora enables consumers to "try on" different makeup with a screen [3]. Nowadays, many apparel retailers have started to invest in virtual fitting room [3]. In this report, it will mainly focus on the popularity of virtual fitting room in the apparel industry.

Two branches: according to Yunqi Jia and Jinghang Zhang, virtual fittingroom technology is applied in two fields [4]. Hardware equipment: The current virtual fitting rooms people see in malls areconsisted of a device with a display screen and fitting software, which scans the user's body parameters through the camera above the 
display screen, and has been placed in public areas in shopping malls. However, the remote value and function of the virtual fitting room could not be reached if it was placed in malls.

Online part: Online fitting software like Taobao and other retail stores that focus on personalization and avant-garde clothing, use virtual fitting application as a means of promotion, intending to increase the novelty of young consumers.

\subsection{Benefits of using virtual fitting room}

\subsubsection{Online part}

In one report written by Yang and Xiong, it was found that, using virtual fitting room can help reduce the return rate [2]. According to Biron, Online apparel suffers from a high return rate, and has a substantial because of the high return [3]. Thus, it is hoped that apparel companies can reduce the cost of return with the help of virtual fitting room.

\subsubsection{In-store part}

One observation of white-collar women's clothing purchase behavior found that: white-collar women are used to walking around venues and waiting to try on all the clothes they like, but the fitting room basically needs to wait in line for more than 10 minutes, so female consumers either choose to wait in line or choose to try on at the clothing store. According to field interviews with female consumers, in the whole process of buying clothes, it is queuing for fitting and payment that waste a lot of time. Waiting in line is the main problem that white-collar female consumers think affects shopping pleasure. With the help of virtual fitting room technology, it is hopedthat the time spent on queuing can be reduced [5].

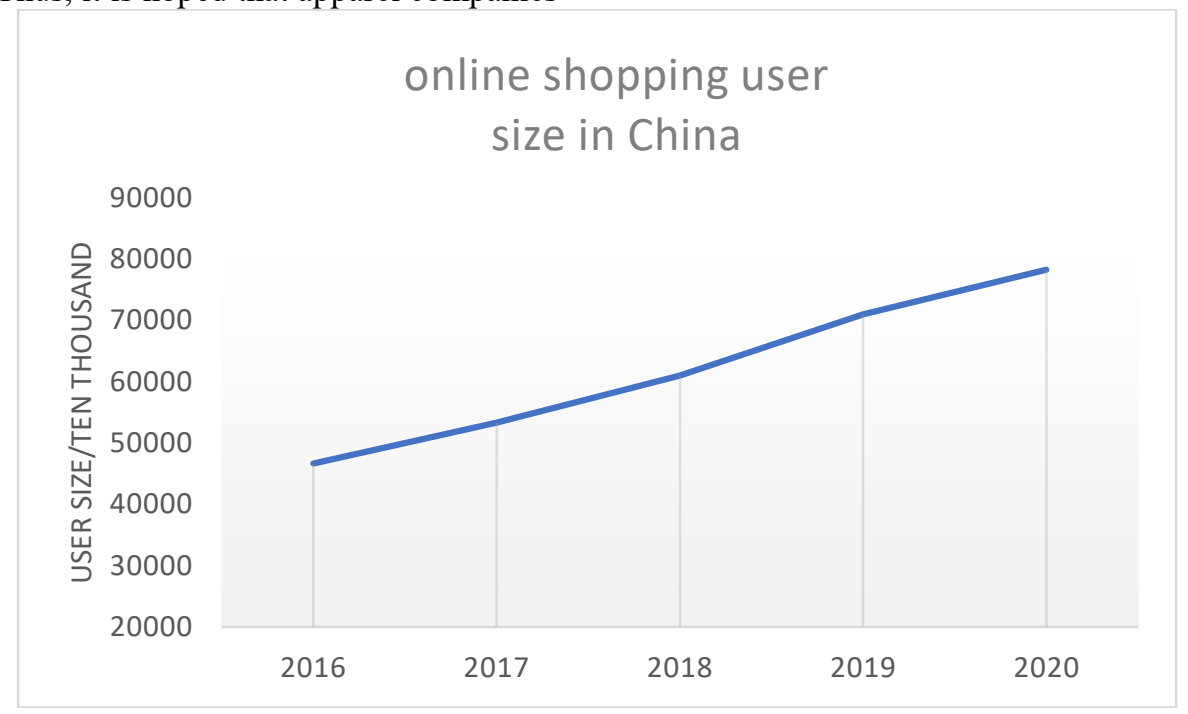

Figure 1 Online shopping user size

\subsection{E-commerce trend in China}

Figure 1 shows the online shopping user size per year in China, which is extracted from the 45th Chinese statistical report on Internet development, of the online shopping user size in China. It is found that the size kept increasing since 2016. In 2020, the size was 0.78241 billion. It is necessary to mention that, in the latest population census in China, there are 1.395 billion people in 2018. Thus, in 2018, there are around half of the Chinses used Internet to do shopping. Besides, it is expected that the size would keep rising in the following years. Thus, the market size for the online fitting room is relatively large [6].

\section{4 policies}

The 13thFive-Year Plan, an official plan launched by Chinese government, emphasized that more attention should be paid to the virtual reality, which may help improve the development of the technology of virtual fitting room [7].

\section{5 new opportunities}

The spread of the COVID-19 pandemic is a tragedy for all human beings. However, the companies developing virtual fitting room (VFR) may find it an opportunity to develop this industry. For example, fashion industry has been challenged by the inability to produce and transport physical garment samples [8]. VFR companies can help solve the problem with their 
special property that they can show the details of clothes online. Thus, apparel companies do not have to spend substantial money on the production and transportation. For example, the VFR company Metail worked with other organization to create virtual clothes to replace the samples for merchandising and consumer testing [8].

\section{6 problems}

\subsubsection{Technology}

In fact, the technology in virtual fitting room is not that advanced.

Inaccurate model

According to Han, Kim and Jeon, the current technology can only show the ideal bodies, which means that the models of different people do not match their actual figure efficiently [9]. This may lead to the inaccuracy of virtual fitting room system, making consumers lose confidence in this technology.

\section{Cannot show details}

The current method is to build a 3D model and then past a texture on it, which is really sufficient for the subsequent processing. However, it is much harder to build models for special textural clothes in details. According to Stitch Meshes, practically, the algorithm for models runs slowly and clothes need to be modeled with special models. Take the simulation of a sweater as an example. The time required to simulate the effect of a sweater on a person is in hours, since the threedimensional model needed is not a traditional mesh model because of the requirement of the microstructure of the sweater [10].

\section{Poor sense of experience}

It is difficult to obtain clothing parameters, and there is a poor sense of experience: the picture effect and imprecision is not good. The integration of animation technology and two-dimensional images of format pictures makes the fitting effect poor. Some netizens say that they feel that the clothes look like they are pasted so there's not a huge actual reference value. Thus, few people will pay for a piece of clothing only because of their virtual fitting experience.

\subsection{2 a narrow market}

When wanting to establish the virtual fitting application, the consumer group is limited, since children and the elderly may not be able to use electronic devices independently. Moreover, the released application must be differentiate from each brand, which means that consumers cannot use one app if they want to experience different brands, leading to the small application population.

\subsection{3 privacy}

Privacy such as personal physical parameters is at risk of being leaked. Most software requires users to open storage, location information, phone and other permissions. If you choose not to agree, you will not be able to install these apps. According to the "2017 Privacy Security and Internet Fraud Analysis Report", mobile network privacy mainly includes mobile phone software acquisition, free WiFi theft, old mobile phone device settings, and hackers stealing corporate big data and other channels [11]. In the era of big data, data is becoming more and more important for businesses. Virtual fitting rooms will try to improve the storage of personal data and pictures and other information, which poses hidden dangers to privacy leakage.

\section{VIRTUAL FITTING SURVEY}

As a technology that faces consumers in the apparel market, it has been proposed many years ago and seems to be a good concept. However, although people in

Western countries are willing to study the application of a new thing, in China, apart from technical barriers, due to the high level of the uncertainty avoidance culture as well as other factors, the huge online market that China owns has not made the virtual fitting room technology continuous expansion, on the contrary, has been a tepid state in recent years. In order to figure out the reason behind, we made a questionnaire survey to ask young people's views on virtual fitting technology. The contents of survey are showed below

\subsection{Survey Structure}

Most of the subjects surveyed are located on the campus of North China University. This group of college students is a group that is full of openness to new technologies. We published a Chinese version of the questionnaire using social software. 


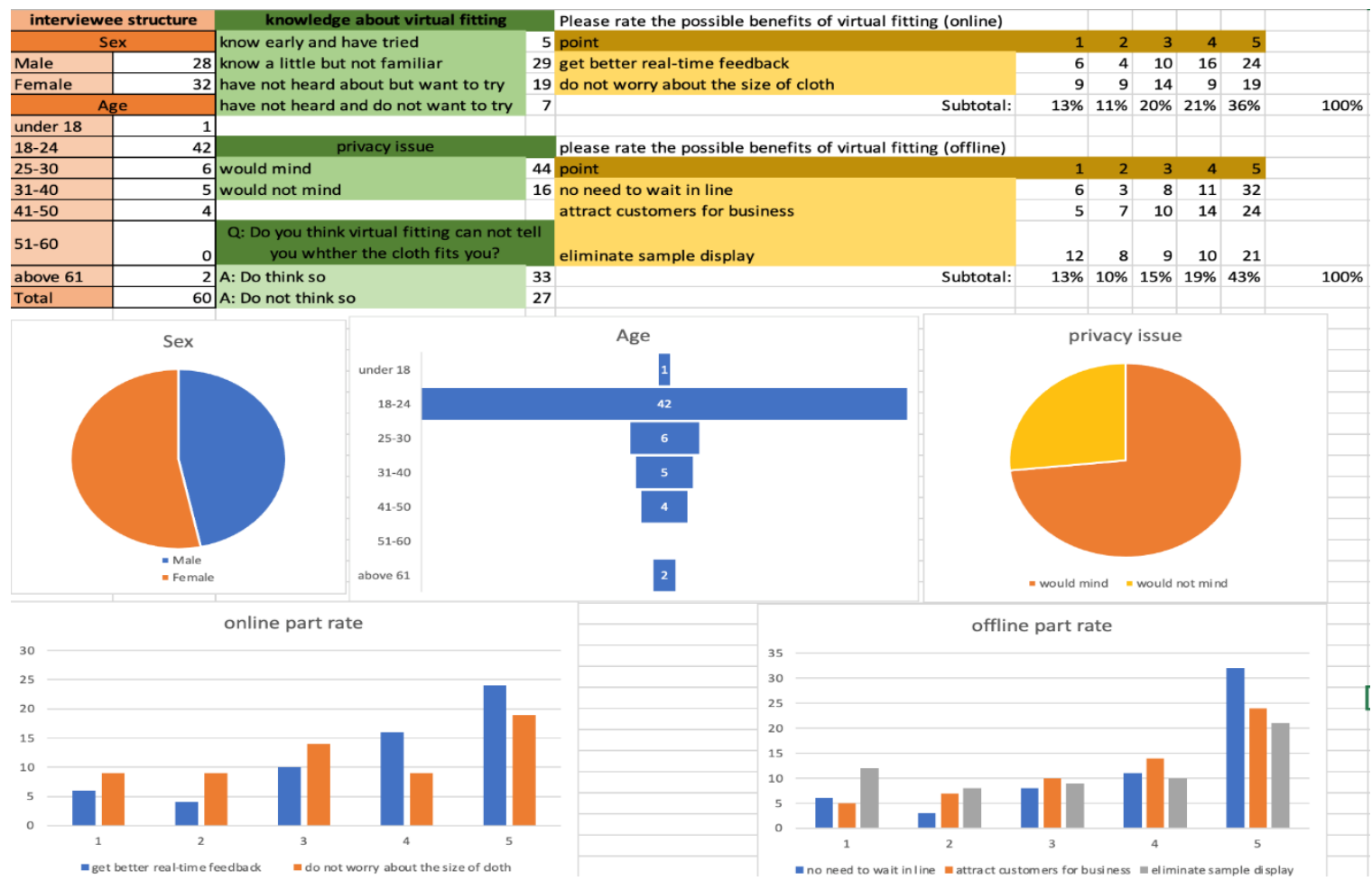

Figure 2 Results of Questionnaire

Figure 2 shows the outcome of the questionnaire.

The number of people surveyed was $60,70 \%$ of the respondents were between 18 and 24 years old, and most of the rest were between 25 and 50 years old. Among them are 32 women and 28 men.

\subsection{Results}

According to the statistics of the final results, more than half of the people said they knew this technology, and only 5 of them said they knew about it and tried it very early. From the result data, it can be seen that most people are relatively unfamiliar with this technology, but everyone is willing to understand and try. $31 \%$ of people learn about virtual fitting technology from the news media, and $21 \%$ are online shopping platforms. Most people agree with the view that virtual fitting technology can solve the offline problem of not having to wait in line in front of

the fitting room. The fact that it can attract customers to businesses is also a powerful reason for them to recognize the use of virtual fitting glasses offline. In the online application part, the respondents also had a relatively good evaluation of the potential benefits. In the last part of the questionnaire, the question is written more simply and clearly so that the answer can be explored. 55\% of the respondents believe that virtual try-on technology cannot tell customers whether the clothes are suitable, and nearly $75 \%$ are worried about privacy issues.

\subsection{Reason Analysis}

Privacy and unsightly interaction are two important issues that will arise after virtual fitting technology is put into practical applications, and it has largely affected the popularity of this technology. Because it is difficult to protect privacy in the information age, when a customer's face and body are scanned in 3D, sensitive biological information such as facial information, height and skin color will be entered. In addition, the user's information may not only be entered by the manufacturer of the virtual fitting room but may also be transmitted to a thirdparty clothing store. Due to the real-time image scanning processing, the unsightly real image will reduce the buyer's desire to try on and greatly reduce the success rate of the purchase. This will lead to the phenomenon of advanced technology and users who do not pay.

\subsection{External factors}

There are also many external factors that may cause the cold field of virtual try-on technology in the Chinese market, compared with the Western side. The product standardization of the virtual fitting room industry is too low. Each manufacturer tends to use its own research and development technology and the technical water products are also different, resulting in a long production cycle and high costs. There are many types of supply chain design in the virtual fitting room industry, and it is difficult for small companies to exist in the market for a long time. Because the initial investment is too large, it is difficult to fight a price war. 


\section{ANALYSIS OF KEY PLAYERS IN VIRTUAL FITTING ROOM.}

Since there are not many companies developing virtual fitting room technology in China. This report would focus on some relative companies in other countries to learn more about the field.

\subsection{Metail}

Metail is a British company focusing on virtual fitting room technology. Their model 'MeModel' allows users to "shop, interact with clothes and get a preview of how garments might drape against their body type [12]." Besides, it is claimed that their accuracy will up to 94$96 \%$ [12]. Figure 3 shows the user interface of MeModel [12].
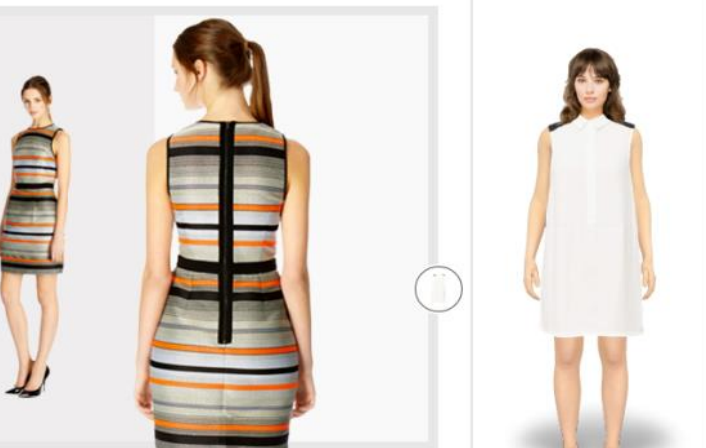

Figure 3 The image of MeModel

\subsubsection{Metail's target consumer}

In fact, Metail's target consumer is not buyers who would buy clothes [12].Instead, Metail usually sells its product to retails [12].Then, the retails rebrand the technology so the end-consumers could see it integrated into the store's e-commerce platform [12].

\subsubsection{The maturity of the development of Metail}

Table 1 is the balance sheet of Metail [13]:

Table 1. balance sheet of MeTail

\begin{tabular}{|c|c|c|c|c|c|c|c|c|c|c|c|}
\hline GBP & $\begin{array}{l}F Y, \\
2008\end{array}$ & $\begin{array}{l}F Y, \\
2009\end{array}$ & $\begin{array}{l}F Y, \\
2010\end{array}$ & $\begin{array}{l}\text { FY, } \\
2011\end{array}$ & $\begin{array}{l}\text { FY, } \\
2012\end{array}$ & $\begin{array}{l}F Y, \\
2013\end{array}$ & $\begin{array}{l}\text { FY, } \\
2014\end{array}$ & $\begin{array}{l}F Y, \\
2015\end{array}$ & $\begin{array}{l}F Y, \\
2016\end{array}$ & $\begin{array}{l}F Y, \\
2017\end{array}$ & $\begin{array}{l}F Y, \\
2018\end{array}$ \\
\hline Cash & $37.5 \mathrm{k}$ & $753 \mathrm{k}$ & $121.6 \mathrm{k}$ & $154.3 \mathrm{k}$ & $68.8 \mathrm{k}$ & $947.1 \mathrm{k}$ & $2000 \mathrm{~m}$ & $708.5 \mathrm{k}$ & $816.8 \mathrm{k}$ & $155.2 \mathrm{k}$ & $71.8 \mathrm{k}$ \\
\hline $\begin{array}{l}\text { Accounts } \\
\text { Receivable }\end{array}$ & & & $49.5 \mathrm{k}$ & $215.7 \mathrm{k}$ & $196.5 \mathrm{k}$ & $279.9 k$ & 679.3k & $48.2 \mathrm{k}$ & $85.2 \mathrm{k}$ & $80.1 \mathrm{k}$ & $31.8 \mathrm{k}$ \\
\hline $\begin{array}{l}\text { Current } \\
\text { Assets }\end{array}$ & $38.9 \mathrm{k}$ & $1.4 \mathrm{k}$ & $171.1 \mathrm{k}$ & $370.0 \mathrm{k}$ & $265.3 \mathrm{k}$ & $1.2 \mathrm{~m}$ & $2.7 \mathrm{~m}$ & $1.4 \mathrm{~m}$ & $1.8 \mathrm{~m}$ & $766.0 \mathrm{k}$ & $735.9 \mathrm{k}$ \\
\hline PP\&E & $3.4 \mathrm{k}$ & $2.7 \mathrm{k}$ & $8.4 \mathrm{k}$ & $25.2 \mathrm{k}$ & $56.1 \mathrm{k}$ & $177.1 \mathrm{k}$ & $299.2 \mathrm{k}$ & $284.9 \mathrm{k}$ & $190.0 \mathrm{k}$ & $121.1 \mathrm{k}$ & $71.8 \mathrm{k}$ \\
\hline Goodwill & & & & & & $113.5 \mathrm{k}$ & $119.6 \mathrm{k}$ & $120.4 k$ & & & \\
\hline
\end{tabular}




\begin{tabular}{|c|c|c|c|c|c|c|c|c|c|c|c|}
\hline GBP & $\begin{array}{l}\text { FY, } \\
2008\end{array}$ & $\begin{array}{l}\text { FY, } \\
2009\end{array}$ & $\begin{array}{l}\text { FY, } \\
2010\end{array}$ & $\begin{array}{l}\text { FY, } \\
2011\end{array}$ & $\begin{array}{l}\text { FY, } \\
2012\end{array}$ & $\begin{array}{l}\text { FY, } \\
2013\end{array}$ & $\begin{array}{l}\text { FY, } \\
2014\end{array}$ & $\begin{array}{l}\text { FY, } \\
2015\end{array}$ & $\begin{array}{l}\text { FY, } \\
2016\end{array}$ & $\begin{array}{l}\text { FY, } \\
2017\end{array}$ & $\begin{array}{l}\text { FY, } \\
2018\end{array}$ \\
\hline Total Assets & $42.3 \mathrm{k}$ & $4.1 \mathrm{k}$ & $179.5 \mathrm{k}$ & $444.8 \mathrm{k}$ & $399.4 k$ & $1500 \mathrm{k}$ & $3200 \mathrm{k}$ & $1900 k$ & $2100 \mathrm{k}$ & $1000 \mathrm{k}$ & $901.7 \mathrm{k}$ \\
\hline $\begin{array}{l}\text { Accounts } \\
\text { Payable }\end{array}$ & & & & $222.7 \mathrm{k}$ & $34.7 \mathrm{k}$ & $102.1 \mathrm{k}$ & $139.2 \mathrm{k}$ & $10.9 \mathrm{k}$ & $109.9 k$ & $59.9 k$ & $128.2 \mathrm{k}$ \\
\hline $\begin{array}{l}\text { Current } \\
\text { Liabilities }\end{array}$ & $18.6 \mathrm{k}$ & $28.4 \mathrm{k}$ & $81.4 \mathrm{k}$ & $222.7 \mathrm{k}$ & $34.7 \mathrm{k}$ & $102.1 \mathrm{k}$ & $139.2 \mathrm{k}$ & $191.0 \mathrm{k}$ & $3.4 \mathrm{~m}$ & $452.9 k$ & $393.9 k$ \\
\hline $\begin{array}{l}\text { Long-term } \\
\text { debt }\end{array}$ & & & & & & & & & & & $4.8 \mathrm{~m}$ \\
\hline $\begin{array}{l}\text { Non-Current } \\
\text { Liabilities }\end{array}$ & & & & & & & & $2.0 \mathrm{~m}$ & $3.0 \mathrm{~m}$ & $439.9 \mathrm{k}$ & $4.8 \mathrm{~m}$ \\
\hline Total Debt & & & & & & & & & & & $4.8 \mathrm{~m}$ \\
\hline $\begin{array}{l}\text { Total } \\
\text { Liabilities }\end{array}$ & $18.6 \mathrm{k}$ & $28.4 \mathrm{k}$ & $81.4 \mathrm{k}$ & $222.7 \mathrm{k}$ & $34.7 \mathrm{k}$ & $102.1 \mathrm{k}$ & $139.2 \mathrm{k}$ & $2.2 \mathrm{~m}$ & $6.4 \mathrm{~m}$ & $892.8 \mathrm{k}$ & $5.2 \mathrm{~m}$ \\
\hline $\begin{array}{l}\text { Common } \\
\text { Stock }\end{array}$ & $18.0 \mathrm{k}$ & $18.0 \mathrm{k}$ & $28.1 \mathrm{k}$ & $37.1 \mathrm{k}$ & $47.7 \mathrm{k}$ & $63.4 \mathrm{k}$ & $78.1 \mathrm{k}$ & $78.1 \mathrm{k}$ & $78.1 \mathrm{k}$ & $101.8 \mathrm{k}$ & $101.8 \mathrm{k}$ \\
\hline $\begin{array}{l}\text { Retained } \\
\text { Earnings }\end{array}$ & & & & & & $(4.0 \mathrm{~m})$ & $(6.1 \mathrm{~m})$ & $(9.4 \mathrm{~m})$ & )$^{(14.3 m}$ & )$^{(19.3 m}$ & $\begin{array}{l}(23.6 m \\
)^{2}\end{array}$ \\
\hline Total Equity & $23.7 \mathrm{k}$ & (24.3k) & $98.1 \mathrm{k}$ & $222.1 \mathrm{k}$ & $364.6 \mathrm{k}$ & $1.4 \mathrm{~m}$ & $3.0 \mathrm{~m}$ & $\begin{array}{l}(317.1 \\
\text { k) }\end{array}$ & $(4.3 \mathrm{~m})$ & $111.6 \mathrm{k}$ & $(4.3 \mathrm{~m})$ \\
\hline $\begin{array}{l}\text { Debt to } \\
\text { Equity Ratio }\end{array}$ & & & & & & & & & & & $-1.1 x$ \\
\hline GBP & $\begin{array}{l}F Y, \\
2008\end{array}$ & $\begin{array}{l}\text { FY, } \\
2009\end{array}$ & $\begin{array}{l}F Y, \\
2010\end{array}$ & $\begin{array}{l}\mathrm{FY} \\
2011\end{array}$ & $\begin{array}{l}F Y, \\
2012\end{array}$ & $\begin{array}{l}\mathrm{FY} \\
2013\end{array}$ & $\begin{array}{l}\mathrm{FY} \\
2014\end{array}$ & $\begin{array}{l}\text { FY, } \\
2015\end{array}$ & $\begin{array}{l}\text { FY, } \\
2016\end{array}$ & $\begin{array}{l}\text { FY, } \\
2017\end{array}$ & $\begin{array}{l}\text { FY, } \\
2018\end{array}$ \\
\hline $\begin{array}{l}\text { Debt to } \\
\text { Assets Ratio }\end{array}$ & & & & & & & & & & & $5.3 x$ \\
\hline $\begin{array}{l}\text { Financial } \\
\text { Leverage }\end{array}$ & $1.8 \mathrm{x}$ & $-0.2 x$ & $1.8 \mathrm{x}$ & $2 x$ & $1.1 \mathrm{x}$ & $1.1 \mathrm{x}$ & $1 \mathrm{x}$ & $-6 x$ & $-0.5 x$ & $9 x$ & $-0.2 x$ \\
\hline
\end{tabular}


From the balance sheet, it can be found that the figures were not stable at all. This might because that the company has not been mature yet. In fact, for the virtual fitting room field, no company has truly taken off on a large scale [12].

\subsection{Zugara}

Based in Los Angeles, Zugara is an American Augmented Reality corporation [14]. In fact, Zugara develops both online and offline virtual fitting room technology [15].

\subsubsection{Virtual Style Sense}

For the in-store branch, in 2014, cooperating with Samsung, Zugara launched a technology called "Virtual Style Sense (VSS)" for the in-store retailers [16]. VSS enables users to digitally see different styles and colors of the clothes in a display[16]. Besides, VSS would also do some analysis to predict the most popular items for retailors [16].

Figure 4 shows the one of its appliances of VSS [16].

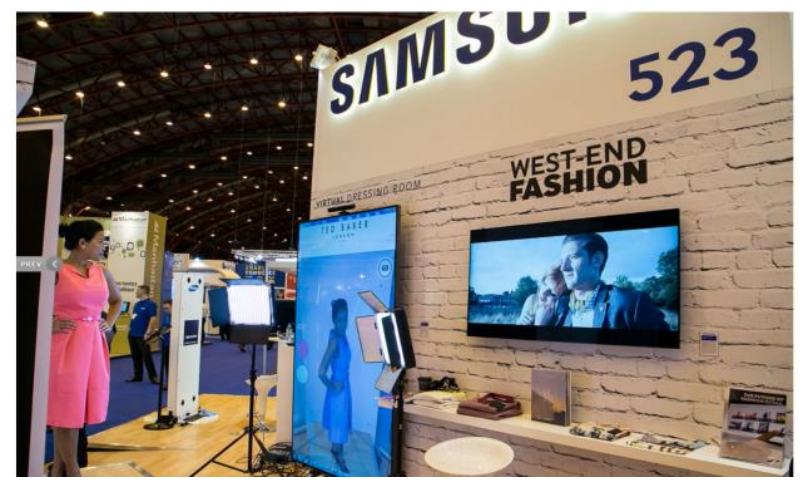

Figure 4 the appliance of Virtual Style Sense

\subsubsection{Zugara's target consumer}

Zugara's target consumers are also the retailors [16] .

\section{FUTURE DEVELOPMENT}

The data obtained from the virtual fitting room can be used for data calculation, information storage can also help designers draw patterns, which greatly increases the accuracy and improves the efficiency of clothing from design to production line. The contradiction between the virtuality of clothing design and the authenticity of fitting has yet to be resolved. Three-dimensional clothing design and fitting systems are developing towards networking, standardization, high simulation, and intelligence.

\section{CONCLUSION}

Virtual fitting technology is worth investing in online and offline, although there are risks in getting rewards. Because the technology is not mature enough, the modeling of this technology is very time-consuming and labor-intensive when faced with various types of clothes, such as the modeling of sweaters. The difference between an ideal figure and an actual figure may ruin the consumer experience. At the same time, the vast majority of people are concerned about the privacy issues of virtual fitting. However, increasing the purchase rate of online clothing, lowering the return rate of merchants and so on have tangibly brought benefits to this market and improved social efficiency. As the virtual fitting technology provides not only provide firms a bunch of data from the consumers who purchase clothes online, but also provide the customer good-quality-andinnovative personalized services such as analyzing user data to accurately recommend products. While the virtual fitting system provide such a benefit to increase the potential revenue for the firms, it is also a benefit that consumers can save their time for lining up and waiting which is a huge factor that leads to less fun during shopping. Finally, due to the impact of the epidemic, companies do not want to spend more on displaying clothes online. They believe that they do not need to spend a lot of money on production and transportation. This advantage is also reflected in the process of reducing the return rate and return cost. In this regard, China can learn from the foreign spirit of innovation, and obtain a win-win situation for corporate growth and total revenue increasing through reasonable business logic and realization channels.

\section{REFERENCES}

[1] Liangchuying, Jianggaoming, Pengjiajia(2018). Research Status and Development Trend of Internet-based Virtual Fitting Systems. China Textile Leader, 93-96

[2] Yang, S., \& Xiong, G. (2019). Try It On! Contingency Effects of Virtual Fitting Rooms. Journal of Management Information Systems, 36(3), 789-822. https://doiorg.ez.xjtlu.edu.cn/10.1080/07421222.2019.16288 94> [Accessed 8 May 2021].

[3] Biron, B., 2020.Retailers like Macy's, Adidas, and Modcloth are turning to virtual fitting rooms to let consumers 'try on' clothing before buying it online. [online] Business Insider. Available at: <Retailers Like Macy's and Adidas Are Turning to Virtual Fitting Rooms (businessinsider.com)> [Accessed 8 May 2021].

[4] 2017 Shaanxi Province University Student Innovation and Entrepreneurship Training Project by Yunqi Jia and Jinghang Zhang. 2019. [online] Available at: $<$ FX361.com $>$ [Accessed 14 May 2021]. 
[5] Analysis of the Demand by White-Collar Women for Virtual Fitting-Room Design. Jialin Huang. 2012. [online] Available at:<Baidu Academic $>$ [Accessed 14 May 2021].

[6] Cac.gov.cn. 2020.The 45th <statistical report on the development of Internet in China> (full text) Office of the network security and Information Technology Commission of the CPC Central Committee(cac.gov.cn)> [Accessed 8 May 2021].

[7] cupiday, 2021.The State Council has written virtual reality into the 13th five year plan for national informatization [online] Sohu.com. Available at: $<$ The State Council writes virtual reality into the 13th five year plan of national informatization(sohu.com)> [Accessed 14 May 2021].

[8] Fibre2fashion.com. 2021.Browzwear \& Metail join hands for garment technology. [online] Available at: <Browzwear \& Metail join hands for garment technology -Fibre2Fashion $>$ [Accessed 8 May 2021].

[9] Han, H., Kim, T. and Jeon, E., 2021.3D standard avatar creation of Korean women in their twenties and thirties by body types for apparel industry. [online] sciencedirect. Available at: <3D standard avatar creation of Korean women in their twenties and thirties by body types for apparel industry ScienceDirect> [Accessed 8 May 2021].

[10] Stitch Meshes by Cem YukselJonathan M. KaldorDoug L. JamesSteve Marschner. 2012. [online] Available at: < Cem Yuksel(http://www.cemyuksel.com/research/stitch meshes/) > [Accessed 14 May 2021].

[11]2017 Privacy Security and Internet Fraud Analysis Report [Accessed 20 May 2021].

[12] Li, C., 2014. One size does not fit all: why Londonbased Metail just raised $\$ 12$ million for its 'online fitting room' - Tech.eu. [online] Tech.eu. Available at: < One size does not fit all: why London-based Metail just raised \$12 million for its 'online fitting room' - Tech.eu > [Accessed 10 May 2021].

[13] craft. 2021. [online] Available at: <Metail Stock / Share Price, Funding Rounds, Valuation and Financials | Craft.co> [Accessed 14 May 2021].

[14] Zugara. 2021. Augmented Reality Startup Los Angeles. [online] Available at: < Augmented Reality Startup Los Angeles (zugara.com)> [Accessed 14 May 2021].

[15] Zugara. 2021. Augmented Reality and Virtual Reality Software. [online] Available at: <
Augmented Reality and Virtual Reality Software (zugara.com)> [Accessed 14 May 2021].

[16] Zugara. 2021. Virtual Style Sense. [online] Available at: < Virtual Style Sense (zugara.com)> [Accessed 14 May 2021]. 